\title{
Influence Factors of People Purchasing on Social Commerce Sites
}

\author{
I-Ping Chiang \\ Graduate Institute of Information Management, National Taipei University \\ E-Mail: ipchiang@mail.ntpu.edu.tw \\ Kai-Chieh Lin \\ Graduate Institute of Information Management, National Taipei University \\ E-Mail: kj051955jay12@gmai.com \\ Chih-Hui Huang \\ Graduate Institute of Information Management, National Taipei University \\ E-Mail: ful67485@gmail.com \\ Wan-Ling Yang \\ Graduate Institute of Information Management, National Taipei University \\ E-Mail: w028w028@gmail.com
}

\begin{abstract}
With the growing use of social media in the world, a wide variety of social media applications and services have been produced. Popular social media platforms leverage their unique functions to persuade their users to adopt such applications and services, and many enterprises have begun to consider social media operations as a crucial aspect. Thus, since the gradual influence of social media on consumer behavior, a new social commerce model has begun to develop. This research examined both business and social aspects of social commerce sites to establish an evaluation model for measuring their quality and effectiveness. We collected 468 valid samples of online users who had used social commerce site to browse or purchase products and were willing to use again. We used EFA and CFA to confirm the model we constructed, and Partial least squares regression was used to analyze the relationship among the antecedents and consequences of quality evaluation in social commerce sites. According to the result, the consumers' behaviors were most likely affected by functionality, enjoyment, process, reliability, presence, and identity with a social commerce site. This study not only provided a credible social commerce quality measurement for other scholars to conduct
\end{abstract}


relevant research but also provide conclusions for the marketing strategy of social commerce sites and products as a reference.

Keywords: Social commerce, Internet marketing, Online shopping, E-commerce

\section{INTRODUCTION}

With the rapid growth of social network services, social networking sites continue to add new features and other applications to their platforms, prompting many brands and commodities to set up fan pages to effectively attract consumers of a specific group. Therefore, many marketing activities can be found on social media websites. According to Pixlee (2015), lots of consumers relying on social media for shopping. Additionally, many small and medium enterprises gained more new consumers by using social media.

Various types of social commerce sites are in existence, covering many aspects, including peer-to-peer sales platforms, social-network-driven sales, group buying, peer recommendations, user-curated shopping, participatory commerce, and social shopping. A social commerce site may also combine several of the features mentioned above; for example, Facebook includes peer-to-peer sales platforms, social-network-driven sales, group buying, and peer recommendations. Therefore, to identify a suitable social commerce site for effective sales of a particular product, it is necessary to identify the perceived properties of individual social commerce sites.

Given the current situation of social commerce sites on the market and in published researches, our study measured the quality of social commerce sites by exploring both their commerce-oriented and social-oriented aspects. Since social commerce sites represent a new model of trade that combines e-commerce and social media function, our study considered both of the aspects for a practical assessment. The data analysis explained how social commerce sites could become the next blooming line of commerce.

Although the academic research on social community platforms was quite diverse, most relevant research focused on concerns regarding the social community and product marketing, few literature foci on social commerce sites. Therefore, our study investigated the service quality of social commerce sites from the commerce-oriented and social-oriented aspects to establish an evaluation model for the quality and effectiveness of such sites. We confirmed the construct of quality in social commerce sites by using factor analysis and explored the causal relationship between the quality of social commerce sites and social commerce performance. Finally, we summarized the empirical results and provided suggestions and conclusions, which could be used as a reference for establishing corporate social marketing strategies and the basis for 
further research in the future. Based on the description above, the purposes of this study were to (a) through literature review, establish the evaluation model of quality and effectiveness assessment of social business website at commerce and social aspects, (b) develop the measurement items of factors, (c) use online questionnaire survey collecting data from consumers of social commerce site and use CFA analysis confirming the composition of each factor, (d) explore the relationships between factors and social commerce performance for the future development of social commerce site. On the other hand, researchers who want to explore social commerce sites in the future can base on this research model to conduct further research.

\section{THEORETICAL BACKGROUND}

\section{Definitions}

In general, a social commerce site is defined as a consumer pattern that allows consumers to participate in marketing activities and sales of products or services through online community platforms (Stephen \& Toubia, 2010; Hajli, 2015). Social commerce sites are broadly divided into two main types: community websites with commercial features such as advertising and trading (e.g., Facebook and LinkedIn), and traditional e-commerce sites with social functions, such as Amazon's community functions that enable business-to-customer websites to understand customer requirements and offer superior customer service (Liang \& Turban 2011; Lu et al., 2016).

Social commerce is a term often used to describe new online retail models or marketing strategies that incorporate established social networks and peer-to-peer communication to drive sales. Although social commerce has all kinds of categories, various social commerce sites have distinct characteristics. Refer to some scholars' papers (Indvik, 2013), the following seven types of social commerce sites are summarized and discussed, respectively.

1. Peer-to-peer sales platforms: These are community-based marketplaces where people communicate with and sell directly to others.

2. Social-network-driven sales: This refers to sales driven by referrals on social networks or fan pages.

3. Group buying: This involves products and services offered at a discounted price if enough buyers make the purchase together.

4. Peer recommendations: Some sites aggregate product or service reviews and recommend products based on other users' purchasing histories. They also stimulate individuals for sharing products and purchases with friends through social networks.

5. User-curated shopping: These are sites where users create and share lists of products and services to enable other users to understand more about them. 
6. Participatory commerce: Consumers are directly involved in the production process through voting, funding, and collaboratively designing products.

7. Social shopping: These sites aim to replicate the experience of shopping with friends, including chat and forum features for exchanging advice and opinions.

\section{Quality Assessments of Social Commerce Sites}

\section{Commerce-oriented quality assessment}

Since social commerce sites are required to provide services directly on the platform, they must possess e-commerce characteristics. Most previously used quality measurement models for e-commerce (E-S-QUAL) established e-shopping behavior as the basis for measurement. However, according to Bauer et al. (2006), practicality and enjoyment are also relevant considerations; therefore, they $\mathrm{d}$ a model for measuring the quality of electronic service transactions (eTransQual). The present study explored the literature on electronic business quality measurement and created a standard for measuring the business quality of social commerce sites based on the following points. Functionality. Zeithaml et al. (2002) indicated that ease of use refers to the functional design of the site and the overall page consistency, design, and guidance. Efficiency refers to obtaining the required information quickly when using websites (Parasuraman et al., 2005), and website functional metrics can be evaluated based on the efficiency of the site's operations (Ho \& Lee, 2007). Bauer et al. (2006) argued that for measuring the quality of e-commerce transaction processes, functionality, ease of use, and efficiency should be considered. Thus, we proposed the first hypothesis:

H1: Social commerce sites' functionality would increase the user's intention to use.

Enjoyment. Enjoyment has been considered a fundamental characteristic of hedonic (Chang \& Tseng 2013; Pappas et al., 2017). Van Riel et al. (2001) said that emotional responses are relevant to the quality of online services; moreover, fun and enjoyment in the experience of online service processes are significant factors that affect the behavior of online users. To completely understand online shopping behaviors, potential entertainment and emotional value should be considered when measuring online service quality (Babin et al., 1994; Holbrook \& Hirschman, 1982). Moreover, providing an enjoyable experience to users improves interactivity (Chan \& Li, 2010; Tsai \& Pai, 2013). Therefore, since the emotional response of consumers is a crucial factor for measuring quality, we proposed the second hypothesis:

H2: Social commerce sites' enjoyment would increase the user's intention to use.

Process. Grönroos et al. (2000) proposed the NetOffer model and indicated that online services could be divided into functional and technical levels. The functional level refers 
to the result of the service, whereas the technology level refers to the process of service; both levels are relevant. Long and McMellon (2004) indicated that during the process of online transactions from order to product delivery, many factors could affect transaction success, and Zehir et al. (2014) highlighted that e-commerce sites also require an efficient order processing capacity. Therefore, we proposed the third hypothesis:

H3: Social commerce sites’ process smoothly would increase the user's intention to use.

Reliability. According to Parasuraman et al. (1988), service commitment is a relevant factor for measuring service quality. Zhou et al. (2012) indicated that the fundamental problem of e-commerce is trust in the e-commerce environment; however, the recommendations of other members on the platform are considered trustworthy (Fassnacht \& Koese, 2006; Lee \& Lin, 2005). If the transaction process does not promote a sense of reliability among buyers and sellers, the transaction may fail both sides of the dispute. Therefore, we proposed the fourth hypothesis:

H4: Social commerce sites' reliability would increase the user's intention to use.

Responsiveness. Customer requests and replies after the provision of products and services can be a measure of online service quality (Bauer et al., 2006). Online service responses considerably affect service quality and customer satisfaction (Yang \& Jun, 2002), and a useful e-commerce site should have a rapid response speed (Ho \& Lee 2007; Long \& McMellon, 2004). Therefore, we proposed a fifth hypothesis:

H5: Social commerce sites' responsiveness would increase the user's intention to use.

\section{Social-oriented quality assessment}

Social commerce sites should offer information exchange functions in addition to possessing the characteristics of a community platform. Kietzman et al. (2012) proposed a model for measuring social media quality. After aggregating other relevant literature on community platform quality measurement, present studies derived the following criteria for measuring the community quality of social commerce sites.

Presence. In an online community, social presence is constituted by members' ability to project their physical and emotional existence (Abdullah, 2004). Presence is an impetus for active participation, particularly for users who enjoy interacting, and speech on a platform creates user awareness of the existence of other real members $(\mathrm{Li} \& \mathrm{Li}$, 2011). Online communities with a high member presence can convince others that the platform has a high degree of authenticity and thus improve their participation in the platform. Social presence has been shown to increase social commerce use intentions 
(Tajvidi, Wang, \& Hajli, 2017). Therefore, we proposed the sixth hypothesis:

H6: Social commerce site members' presence would increase the user's intention to use.

Identity. People compare themselves with others to confirm that their ideas are correct and supported in the community (Festinger, 1954). A sense of self \& group membership can be constructed through the comparison of similarities (Ellegaard, 2012), and people can prove themselves through the attributes and traits common to the community to establish trust and attribution with other members (Zhao et al. 2012). People consider whether they have a common goal with other members on a platform (Corbitt et al., 2003) and seek to communicate with community members who are highly similar to themselves. Therefore, we proposed the seventh hypothesis:

H7: Social commerce site members' identity would increase the user's intention to use.

Interaction. This refers to the exchange of information between two or more subjects (Rafaeli \& Sudweeks, 1997), and it may be positively correlated with loyalty (Alba et al., 1997). A higher level of interaction may increase consumer loyalty to the platform. Interaction measurement entails the ease of communication between individuals and the closeness between individuals (Scoble \& Israel, 2006) and whether the members of the platform communicate well (Carlson \& Zmud, 1999). Therefore, we proposed the following hypothesis:

H8: Social commerce site members' interaction would increase the user's intention to use.

Reciprocity. This refers to a sense of responsibility among community members to help each other (Kollock, 1999). Munzel and Kunz (2014) showed that online users perceived a social debt that they need to give something back to the online system, which can also be called reciprocity. Community members must have intensive reciprocity to have the ability to share knowledge (Wasko \& Faraj, 2005), and members should be able to both locate help through the platform and help other members (Top et al., 2011). Reciprocity is a vital element for generating a sense of community. Hence, we proposed the final hypothesis:

H9: Social commerce site members' reciprocity would increase the user's intention to use.

\section{Social Commerce Performance Indicators}

This study explored the changes in consumer behavior generated by new types of social commerce sites based on the buying experience of consumers. To enhance the future development of social commerce sites, we analyzed the willingness of consumers 
to reuse such websites based on the following factors.

\section{Social commerce performance}

The intention is a common axis for studying human behavior. Social commerce intention includes sharing the experience of buying products or services with others and the loyalty of the consumers (Liang et al., 2011). Therefore, our study investigated the effect of the quality assessment of social commerce sites on social commerce intention.

eWOM. eWOM is an effect, a transfer of information through social networks. It frequently occurs in a spontaneous manner (Salzman et al., 2004). eWOM is the interpersonal communication between two or more individuals (Kim et al., 2001). eWOM is defined as an informal verbal communication occurring in person, by telephone, email, or any other communication method regarding a service or a good. A recommendation source may be personal or impersonal (Goyette et al., 2010). As well as the initiative to share good experiences with others (Severi et al., 2014).

Loyalty. The concept and degree of loyalty are one of the critical indicators used to measure the success of marketing (Flavian et al., 2001). The loyalty of consumers could be one of the main factors that strengthen the market competitiveness and to reinforce sustainable competitive advantage since appealing to new customers is remarkably more costly than retaining existing customers (Kuo, Hu \& Yang, 2013). Loyalty has been measured in one of the following ways: the behavioral approach, the attitudinal approach, and the composite approach (Jacoby \& Chestnut, 1978). Shopping loyalty exists when repeated buying behavior reflects a friendly attitude toward a brand (Keller, 1993). Since consumers can compare products and prices online immediately, which renders online trading situations more intense, loyalty is critical (Yang \& Peterson, 2004). Therefore, loyalty is a crucial operational performance indicator of social commerce sites.

\section{METHODOLOGY}

\section{Conceptual Framework and Measures}

The questionnaire in this research, which was developed based on the literature, comprised 47 questions to measure the quality of social commerce sites and adopted a six-point Likert-type scale ranging from 1 (strongly disagree) to 6 (strongly agree). Various social commerce sites users were our observation targets for exploring the influence of social commerce site quality on the user's social commerce performance. An expert review meeting was conducted before the questionnaire survey. Experts were required to make recommendations based on the content of the questionnaire to make 
it more qualified. Figure 1 presents the conceptual framework.

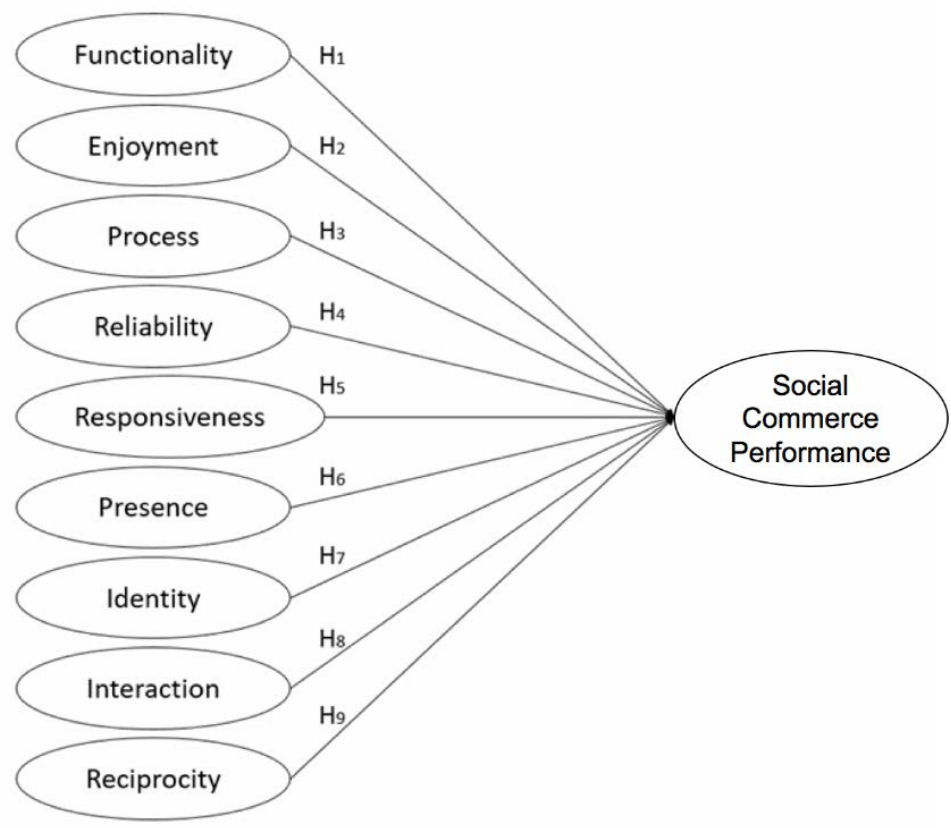

Fig. 1. Conceptual framework

\section{Data Collection}

This study conducted an online survey through PTT forum and Facebook. The survey collected 468 valid samples of online users who had experience using social commerce site to browse or purchase products and were willing to use again. There were $46.4 \%$ male $(n=217)$ and $53.6 \%$ female $(n=251) ; 27.1 \%$ younger than 20 years old $(\mathrm{n}=127), 61.5 \%$ between 21 and 30 years old $(\mathrm{n}=288), 10.5 \%$ between 31 and 40 years old $(n=49)$, and $0.9 \%$ of 40 years old or above $(n=4)$. Furthermore, $45.1 \%$ of the participants were buying consumer electronics $(n=211)$, and $54.9 \%$ were buying footwear $(\mathrm{n}=257)$.

\section{Reliability and Validity}

Considering the sample size, Smart PLS 3.0 was used for structural model evaluation to examine the parameter estimation and the causal relationship between each construct of the overall model as well as to examine the hypotheses.

To test the reliability, we calculated Cronbach's $\alpha$, the composite reliabilities (CR), and the average variance extracted (AVE) for all constructs. The result is as follows: functionality (Cronbach's $\alpha=0.77, \mathrm{CR}=0.77$, AVE $=0.53$ ), enjoyment (Cronbach's $\alpha$ $=0.82, \mathrm{CR}=0.80, \mathrm{AVE}=0.57$ ), process (Cronbach's $\alpha=0.86, \mathrm{CR}=0.87, \mathrm{AVE}=$ 0.67), reliability (Cronbach's $\alpha=0.90, \mathrm{CR}=098$., AVE $=0.78$ ), responsiveness (Cronbach's $\alpha=077 ., \mathrm{CR}=0.77, \mathrm{AVE}=0.53$ ), presence (Cronbach's $\alpha=0.83, \mathrm{CR}=$ 
0.90, AVE $=0.61$ ), identity (Cronbach's $\alpha=0.92, \mathrm{CR}=0.91, \mathrm{AVE}=0.64)$, interaction (Cronbach's $\alpha=0.89, \mathrm{CR}=0.90, \mathrm{AVE}=064$.), reciprocity (Cronbach's $\alpha=0.93$, CR $=0.92, \mathrm{AVE}=0.77$, eWOM (Cronbach's $\alpha=0.90, \mathrm{CR}=0.89, \mathrm{AVE}=0.62)$, loyalty (Cronbach's $\alpha=0.85, \mathrm{CR}=0.86, \mathrm{AVE}=0.68$ ).

This study used CFA analysis to test the validity, the result is as follows: commerceoriented quality assessment $(\mathrm{RMSEA}=0.051$, NFI $=0.99$, IFI $=0.99$, NNFI $=0.99$, $\mathrm{CFI}=0.99$, d.f. $\left.=54, \mathrm{x}^{2}=164.22\right)$, social-oriented quality assessment $(\mathrm{RMSEA}=0.066$, $\mathrm{NFI}=0.99$, IFI $=0.99$, NNFI $=0.98$, CFI $=0.99$, d.f. $\left.=130, x^{2}=597.42\right)$, social commerce performance $(\mathrm{RMSEA}=0.052$, NFI $=0.99$, IFI $=1.00, \mathrm{NNFI}=0.99$, CFI $=1.00$, d.f. $\left.=12, x^{2}=38.11\right)$.

\section{Data Analysis}

\section{FINDINGS}

Based on PLS results of all products (see Table1), first of all, the higher the quality of the users' perceived functionality, enjoyment, process, reliability, presence, or identity of a social commerce site was, the higher the intent to use was; thus, $\mathrm{H}_{1}-\mathrm{H}_{4}$, $\mathrm{H}_{6}$, and $\mathrm{H}_{7}$ were supported. However, greater perceive of user's responsiveness, interaction, and reciprocity did not have this effect; therefore, $\mathrm{H}_{5}, \mathrm{H}_{8}$, and $\mathrm{H}_{9}$ were not supported. The overall path analysis results are summarized in the following table. 
Table 1. PLS result for all products

\begin{tabular}{|c|c|c|c|c|}
\hline & $\begin{array}{c}\text { Path } \\
\text { coefficient }\end{array}$ & T Statistics & P Values & Result \\
\hline $\begin{array}{c}\mathrm{H}_{1}: \text { Functionality } \rightarrow \text { Social } \\
\text { commerce performance }\end{array}$ & 0.154 & 4.159 & 0.000 & Supported \\
\hline $\begin{array}{c}\mathrm{H}_{2}: \text { Enjoyment } \rightarrow \text { Social } \\
\text { commerce performance }\end{array}$ & 0.057 & 1.708 & 0.044 & Supported \\
\hline $\begin{array}{c}\mathrm{H}_{3}: \text { Process } \rightarrow \text { Social } \\
\text { commerce performance }\end{array}$ & 0.394 & 10.811 & 0.000 & Supported \\
\hline $\begin{array}{c}\mathrm{H}_{4}: \text { Reliability } \rightarrow \text { Social } \\
\text { commerce performance }\end{array}$ & 0.056 & 1.674 & 0.048 & Supported \\
\hline $\begin{array}{c}\mathrm{H}_{5}: \text { Responsiveness } \rightarrow \text { Social } \\
\text { commerce performance }\end{array}$ & -0.021 & 0.673 & 0.251 & $\begin{array}{c}\text { Not } \\
\text { Supported }\end{array}$ \\
\hline $\begin{array}{c}\mathrm{H}_{6}: \text { Presence } \rightarrow \text { Social } \\
\text { commerce performance }\end{array}$ & 0.199 & 6.226 & 0.000 & Supported \\
\hline $\begin{array}{c}\mathrm{H}_{7}: \text { Identity } \rightarrow \text { Social } \\
\text { commerce performance }\end{array}$ & 0.297 & 6.213 & 0.000 & Supported \\
\hline $\begin{array}{c}\mathrm{H}_{8}: \text { Interaction } \rightarrow \text { Social } \\
\text { commerce performance }\end{array}$ & 0.022 & 0.399 & 0.345 & $\begin{array}{c}\text { Not } \\
\text { Supported }\end{array}$ \\
\hline $\begin{array}{c}\mathrm{H}_{9}: \text { Reciprocity } \rightarrow \text { Social } \\
\text { commerce performance }\end{array}$ & 0.005 & 0.089 & 0.465 & Not \\
\hline
\end{tabular}

Secondly, based on PLS results of consumer electronics (see Table2), the test results of the effect of the various quality assessments on social commerce site use intention are as follows. The higher the quality of the users' perceived functionality, enjoyment, process, reliability, presence, or interaction of a social commerce site was, the higher the intent to use was; thus, $\mathrm{H}_{1}-\mathrm{H}_{4}, \mathrm{H}_{6}$, and $\mathrm{H}_{8}$ were supported. However, more excellent perceived responsiveness, identity, and reciprocity did not have this effect; therefore, $\mathrm{H}_{5}, \mathrm{H}_{7}$, and $\mathrm{H}_{9}$ were not supported. The overall path analysis results are summarized in the following table. 
Table 2. PLS result for consumer electronics

\begin{tabular}{|c|c|c|c|c|}
\hline & $\begin{array}{c}\text { Path } \\
\text { coefficient }\end{array}$ & T Statistics & P Values & Result \\
\hline $\begin{array}{r}\mathrm{H}_{1}: \text { Functionality } \rightarrow \text { Social } \\
\text { commerce performance }\end{array}$ & 0.119 & 2.017 & 0.022 & Supported \\
\hline $\begin{aligned} & \mathrm{H}_{2}: \text { Enjoyment } \rightarrow \text { Social } \\
& \text { commerce performance }\end{aligned}$ & 0.214 & 3.304 & 0.001 & Supported \\
\hline $\begin{aligned} \mathrm{H}_{3}: & \text { Process } \rightarrow \text { Social } \\
& \text { commerce performance }\end{aligned}$ & 0.264 & 4.285 & 0.000 & Supported \\
\hline $\begin{aligned} & \mathrm{H}_{4} . \text { Reliability } \rightarrow \text { Social } \\
& \text { commerce performance } \\
&\end{aligned}$ & 0.168 & 3.196 & 0.001 & Supported \\
\hline $\begin{array}{c}\mathrm{H}_{5}: \text { Responsiveness } \rightarrow \text { Social } \\
\text { commerce performance }\end{array}$ & 0.033 & 0.730 & 0.233 & $\begin{array}{c}\text { Not } \\
\text { Supported }\end{array}$ \\
\hline $\begin{aligned} \mathrm{H}_{6}: & \text { Presence } \rightarrow \text { Social } \\
& \text { commerce performance }\end{aligned}$ & 0.120 & 2.414 & 0.008 & Supported \\
\hline $\begin{aligned} & \mathrm{H}_{7} \text { : Identity } \rightarrow \text { Social } \\
& \text { commerce performance } \\
&\end{aligned}$ & 0.089 & 1.264 & 0.103 & $\begin{array}{c}\text { Not } \\
\text { Supported }\end{array}$ \\
\hline $\begin{aligned} & \mathrm{H}_{8}: \text { Interaction } \rightarrow \text { Social } \\
& \text { commerce performance }\end{aligned}$ & 0.120 & 1.759 & 0.040 & Supported \\
\hline $\begin{aligned} & \mathrm{H}_{9}: \text { Reciprocity } \rightarrow \text { Social } \\
& \text { commerce performance }\end{aligned}$ & 0.000 & 0.002 & 0.499 & $\begin{array}{c}\text { Not } \\
\text { Supported }\end{array}$ \\
\hline
\end{tabular}

Finally, based on PLS results of footwear (see Table3), the test results of the effect of the various quality assessments on social commerce site use intention are as follows. The higher the quality of the users' perceived functionality, process, presence, or identity of a social commerce site was, the higher the intent to use was; thus, $\mathrm{H}_{1}, \mathrm{H}_{3}, \mathrm{H}_{6}$, and $\mathrm{H}_{7}$ were supported. However, greater perceived user enjoyment, reliability, responsiveness, interaction, and reciprocity did not have this effect; therefore, $\mathrm{H}_{2}, \mathrm{H}_{4}$, $\mathrm{H}_{5}, \mathrm{H}_{8}$, and $\mathrm{H}_{9}$ were not supported. The overall path analysis results are summarized in the following table. 
Table 3. PLS result for footwear

\begin{tabular}{|c|c|c|c|c|}
\hline & $\begin{array}{c}\text { Path } \\
\text { coefficient }\end{array}$ & T Statistics & P Values & Result \\
\hline $\begin{array}{c}\mathrm{H}_{1}: \text { Functionality } \rightarrow \text { Social } \\
\text { commerce performance }\end{array}$ & 0.163 & 2.974 & 0.002 & Supported \\
\hline $\begin{array}{c}\mathrm{H}_{2}: \text { Enjoyment } \rightarrow \text { Social } \\
\text { commerce performance }\end{array}$ & -0.062 & 1.485 & 0.069 & $\begin{array}{c}\text { Not } \\
\text { Supported }\end{array}$ \\
\hline $\begin{array}{c}\mathrm{H}_{3}: \text { Process } \rightarrow \text { Social } \\
\text { commerce performance }\end{array}$ & 0.464 & 8.744 & 0.000 & Supported \\
\hline $\begin{array}{c}\mathrm{H}_{4}: \text { Reliability } \rightarrow \text { Social } \\
\text { commerce performance }\end{array}$ & -0.019 & 0.334 & 0.369 & $\begin{array}{c}\text { Not } \\
\text { Supported }\end{array}$ \\
\hline $\begin{array}{c}\mathrm{H}_{5}: \text { Responsiveness } \rightarrow \text { Social } \\
\text { commerce performance }\end{array}$ & -0.045 & 0.903 & 0.183 & $\begin{array}{c}\text { Not } \\
\text { Supported }\end{array}$ \\
\hline $\begin{array}{c}\mathrm{H}_{6}: \text { Presence } \rightarrow \text { Social } \\
\text { commerce performance }\end{array}$ & 0.315 & 7.822 & 0.000 & Supported \\
\hline $\begin{array}{c}\mathrm{H}_{7}: \text { Identity } \rightarrow \text { Social } \\
\text { commerce performance }\end{array}$ & 0.410 & 8.186 & 0.000 & Supported \\
\hline $\begin{array}{c}\mathrm{H}_{8}: \text { Interaction } \rightarrow \text { Social } \\
\text { commerce performance }\end{array}$ & 0.059 & 0.678 & 0.249 & $\begin{array}{c}\text { Not } \\
\text { Supported }\end{array}$ \\
\hline $\begin{array}{c}\mathrm{H}_{9}: \text { Reciprocity } \rightarrow \text { Social } \\
\text { commerce performance }\end{array}$ & -0.064 & 0.736 & $\begin{array}{c}\text { Not } \\
\text { Supported }\end{array}$ \\
\hline
\end{tabular}

\section{CONCLUSION}

The study investigated the establishment of an evaluation model for the quality and effectiveness of a social commerce site in its commercial and social aspect through a literature review to develop measurements. By the method of an online survey, information of consumers who have shopping experience of consumer electronics and footwear products on social commerce sites would be collected.

According to the research result of influential factors on consumers' social commerce intention from a social commerce website, their behaviors were most likely affected by functionality, enjoyment, process, reliability, presence, and identity with a social commerce site. The result showed that consumers were more interested in functionality, enjoyment, process, reliability, presence, and identity on the network, as these factors could directly improve loyalty and enhance consumers' will to recommend the site. The excellent user interface would increase the user's social commerce intention, which was similar to the study of Bauer et al. (2006). Social commerce sites' quality of purchase process would increase the user's intention, which was similar to Chan and Li (2010). Social commerce sites' reliability of information would increase 
the user's intention, which was similar to the study of Long and McMellon (2004). Social commerce members' sense of presence with other members would increase the user's intention, which was similar to Zhou et. Al. (2012). Social commerce members' sense of identity with other members would increase the user's intention, which was similar to c et al. (2012) and Ellegaard (2012). Besides, responsiveness, interaction, and reciprocity would not enhance social commerce performance. Responsiveness, interaction, and mutual assistance of a platform would not encourage consumers to recommend or improve their loyalty.

Table 4. PLS result and Multi-Group Analysis

\begin{tabular}{|l|c|c|c|}
\hline & $\begin{array}{c}\text { All } \\
\text { products }\end{array}$ & $\begin{array}{c}\text { Consumer } \\
\text { electronics }\end{array}$ & Footwears \\
\hline $\begin{array}{c}\mathrm{H}_{1}: \text { Functionality } \rightarrow \text { Social commerce } \\
\text { performance }\end{array}$ & True & True & True \\
\hline $\mathrm{H}_{2}:$ Enjoyment $\rightarrow$ Social commerce performance & True & True & False \\
\hline $\mathrm{H}_{3}:$ Process $\rightarrow$ Social commerce performance & True & True & True \\
\hline $\mathrm{H}_{4}:$ Reliability $\rightarrow$ Social commerce performance & True & True & False \\
\hline $\begin{array}{c}\mathrm{H}_{5}: \text { Responsiveness } \rightarrow \text { Social commerce } \\
\text { performance }\end{array}$ & False & False & False \\
\hline $\mathrm{H}_{6}:$ Presence $\rightarrow$ Social commerce performance & True & True & True \\
\hline $\mathrm{H}_{7}:$ Identity $\rightarrow$ Social commerce performance & True & False & True \\
\hline $\mathrm{H}_{8}:$ Interaction $\rightarrow$ Social commerce performance & False & True & False \\
\hline $\begin{array}{c}\mathrm{H}_{9}: \text { Reciprocity } \rightarrow \text { Social commerce } \\
\text { performance }\end{array}$ & False & False & False \\
\hline
\end{tabular}

Regardless of all products, consumer electronics or footwear products, functionality, process, and presence would increase social commerce performance. This suggested that a social commerce site, regardless of the type of product, should always consider the quality of functionality, process, and presence as the critical factors of quality. Enjoyment and reliability could increase social commerce performance in all products, consumer electronics, and footwear products. The study speculated that consumers would require more information to assist them in selecting the correct purchase of consumer electronics. Thus, the reliability of the information on a social commerce site became essential. On the other hand, consumers might feel more enjoyed to improve their social commerce intention if more information could be presented through videos or activities. For footwear products, enjoyment and reliability could not enhance their social commerce intention. Identity would improve social commerce performance in all products and footwear products. This study deduced that consumers of footwear 
products were more interested in similarity of experience in other members of the social commerce site than consumers of consumer electronics. If members of a social commerce site expressed similar experience, the consumer would be able to find more favorable product. The interaction would only enhance social commerce intention in consumers of consumer electronics, as shown by Carlson and Zmud (1999). The study deduced that consumer electronics were sophisticated in specifications and evolved rather quickly, and interaction with other members of the social commerce site could effectively solve some doubts and increase social commerce performance. Lastly, responsiveness and reciprocity were not able to improve social commerce performance.

This study provided a quality model that can assist in developing marketing strategies for social commerce sites and future products. The types of existing social commerce sites are diverse, and the primary task of the marketing staff is identifying the distinct characteristics of each site and using the characteristics to sell particular products. Moreover, by considering two separate product categories, this study found that different qualities are relevant to consumers' willingness to use social commerce sites for different products. However, this study has some limitations. Since this research targeted online consumers in Taiwan, the results have limited applicability to different cultural settings. Moreover, only a small proportion of respondents were older than 40 years, possibly signifying that such consumers prefer to trade face to face; therefore, our results may not be applied to consumers in this age range.

Although this study was concerned about different social commerce sites and different products, since time and cost considerations, it could not include all social commerce sites; moreover, it did not include diverse product categories comprehensively. This study also focused only on high-traffic business sites and products. Future work should incorporate more social commerce sites such as Amazon and Taobao and cover a broader range of product types to explore the differences, similarities, or other relevance by using PLS, thus providing social commerce sites a reference for deriving product strategies. Moreover, future work could improve the quality scale by expanding it to include qualities not considered in this study (e.g., privacy and security).

\section{REFERENCES}

Abdullah, S. (2004, Oct.). Perilaku oportunistik legislatif dalam penganggaran daerah: Pendekatan Principal-Agent Theory. In the International Seminar at the University of Bengkulu, Bengkulu. Retrieved from

https://www.researchgate.net/publication/303961090_PERILAKU_OPORTUNIS TIK_LEGISLATIF_DALAM_PENGANGGARAN_DAERAH_PENDEKATAN _PRINCIPAL-AGENT_THEORY 
Alba, E. D., Rico, M., \& Jiménez, M. (1997). Cross-strand side-chain interactions versus turn conformation in $\beta$-hairpins. Protein Science, 6(12), 2548-2560. https://doi.org/10.1086/209376

Babin, B. J., Darden, W. R., \& Griffin, M. (1994). Work and/or fun: measuring hedonic and utilitarian shopping value. Journal of Consumer Research, 20(4), 644-656. https://doi.org/10.1086/209376

Bauer, H. H., Falk, T., \& Hammerschmidt, M. (2006). eTransQual: A transaction process-based approach for capturing service quality in online shopping. Journal of Business Research, 59(7), 866-875. https://doi.org/10.1016/j.jbusres.2006.01.021

Carlson, J. R., \& Zmud, R. W. (1999). Channel expansion theory and the experiential nature of media richness perceptions. Academy of Management Journal, 42(2), 153-170. https://doi.org/10.2307/257090

Chan, K. W., \& Li, S. Y. (2010). Understanding consumer-to-consumer interactions in virtual communities: The salience of reciprocity. Journal of Business Research, 63(9), 1033-1040. https://doi.org/10.1016/j.jbusres.2008.08.009

Chang, E. C. and Y. F. Tseng. (2013) Research note: E-store image, perceived value and perceived risk. Journal of Business Research, 66(7), 864-870. https://doi.org/10.1016/j.jbusres.2011.06.012

Corbitt, B. J., Thanasankit, T., \& Yi, H. (2003). Trust and e-commerce: a study of consumer perceptions. Electronic Commerce Research and Applications, 2(3), 203-215. https://doi.org/10.1016/s1567-4223(03)00024-3

Ellegaard-Jensen, L., Jensen, K. A., \& Johansen, A. (2012). Nano-silver induces doseresponse effects on the nematode Caenorhabditis elegans. Ecotoxicology and Environmental Safety, 80, 216-223. https://doi.org/10.1016/j.ecoenv.2012.03.003

Fassnacht, M., \& Koese, I. (2006). Quality of electronic services conceptualizing and testing a hierarchical model. Journal of Service Research, 9(1), 19-37. https://doi.org/10.1177/1094670506289531

Festinger, L. (1954). A theory of social comparison processes. Human Relations, 7(2), 117-140. https://doi.org/10.1177/001872675400700202

Flavian, C., Martinez, E., \& Polo, Y. (2001). Loyalty to grocery stores in the Spanish market of the 1990s. Journal of Retailing and Consumer Services, 8, 85-93. https://doi.org/10.1016/s0969-6989(99)00028-4

Goyette, I., Ricard, L., Bergeron, J., \& Marticotte, F. (2010). e-WOM Scale: word-ofmouth measurement scale for e-services context. Canadian Journal of Administrative Sciences, 27(1), 5-23. https://doi.org/10.1002/cjas.129

Grönroos, C., Heinonen, F., Isoniemi, K., \& Lindholm, M. (2000). The NetOffer model: A case example from the virtual marketspace. Management Decision, 38(4), 243- 
252. https://doi.org/10.1108/00251740010326252

Hajli, N. (2015). Social commerce constructs and consumer's intention to buy. International Journal of Information Management, 35(2), 183-191. https://doi.org/10.1016/j.ijinfomgt.2014.12.005

Hirschman, E. C., \& Holbrook, M. B. (1982). Hedonic consumption: Emerging Concepts, methods and propositions. Journal of Marketing, 46 (Summer), 92-101. https://doi.org/10.2307/1251707

Ho, C. I., \& Lee, Y. L. (2007). The development of an e-travel service quality scale. Tourism management, 28(6), 1434-1449. https://doi.org/10.1016/j.tourman.2006.12.002

Indvik, L. (2013). The 7 species of social commerce. (2013). Retrieved from https://mashable.com/2013/05/10/social-commerce-definition/

Jacoby, J., \& Chesnut, R. W. (1978). Brand loyalty measurement and management. New York: Wiley.

Keller, K. L. (1993). Conceptualizing, measuring., \& managing customer-based brand equity, Journal of Marketing, 57 (January), 1-22

https://doi.org/10.1177/002224299305700101

Kietzmann, J. H., Silvestre, B. S., McCarthy, I. P., \& Pitt, L. F. (2012). Unpacking the social media phenomenon: Towards a research agenda. Journal of Public Affairs, 12(2), 109-119. https://doi.org/10.1002/pa.1412

Kim, W. G., Han, J. S., \& Lee, E. (2001). Effects of relationship marketing on repeat purchase and Word of Mouth. Journal of Hospitality \& Tourism Research, 25(3), 272-288. https://doi.org/10.1177/109634800102500303

Kuo, Y.F., Hu, T.L., Yang, S.C. (2013). Effects of inertia and satisfaction in female online shoppers on repeat-purchase intention: The moderating roles of word-ofmouth and alternative attraction. Managing Service Quality: An International Journal, 23, 168-187. https://doi.org/10.1108/09604521311312219

Lee, G. G., \& Lin, H. F. (2005). Customer perceptions of e-service quality in online shopping. International Journal of Retail \& Distribution Management, 33(2), 161176. https://doi.org/10.1108/09590550510581485

Li, F., \& Li, Y. (2011). Usability evaluation of e-commerce on B2C websites in China. Procedia Engineering, 15, 5299-5304.

https://doi.org/10.1016/j.proeng.2011.08.982

Liang, T. P., Ho, Y. T., Li, Y. W., \& Turban, E. (2011). What drives social commerce: The role of social support and relationship quality. International Journal of Electronic Commerce, 16(2), 69-90. https://doi.org/10.2753/jec1086-4415160204

Long, M., \& McMellon, C. (2004). Exploring the determinants of retail service quality on the Internet. Journal of services marketing, 18(1), 78-90. 
https://doi.org/10.1108/08876040410520726

Lu, B., Fan, W., \& Zhou, M. (2016). Social presence, trust, and social commerce purchase intention: An empirical research. Computers in Human Behavior, 56, 225-237. https://doi.org/10.1016/j.chb.2015.11.057

Wasko, M.M. \& Faraj, S. (2005). Why should I share? Examining social capital and knowledge contribution in electronic networks of practice. MIS Quarterly, 29(1) 35-57. https://doi.org/10.2307/25148667

Tajvidi, M., Wang, Y., Hajli, N., \& Love, P. E. (2017). Brand value Co-creation in social commerce: The role of interactivity, social support, and relationship quality. Computers in Human Behavior, 10(Nov). https://doi.org/10.1016/j.chb.2017.11.006

Kollock, P. The economies of online cooperation: Gifts and public goods in Cyberspace. In M. Smith \& P. Kollock (eds), Communities in cyberspace (pp.220-239). New York, N.Y.: Routledge.

Pappas, I. O., Kourouthanassis, P. E., Giannakos, M. N., \& Lekakos, G. (2017). The interplay of online shopping motivations and experiential factors on personalized e-commerce: A complexity theory approach. Telematics and Informatics, 34(5), 730-742. https://doi.org/10.1016/j.tele.2016.08.021

Parasuraman, A., Zeithaml, V. A., \& Berry, L. L. (1988). SERVQUAL: A multiple-item scale for measuring consumer perceptions of service quality. Journal of Retailing, 64(1), 12-40. https://doi.org/10.1177/1094670504271156

Parasuraman, A., Zeithaml, V. A., \& Malhotra, A. (2005). E-S-Qual: A multiple-item scale for assessing electronic service quality. Journal of Service Research, 7(3), 213-233. https://doi.org/10.1177/1094670504271156

Rafaeli, S., \& Sudweeks, F. (1997). Networked interactivity. Journal of ComputerMediated Communication, 2(4).

https://doi.org/10.1111/j.1083-6101.1997.tb00201.x

Salzman, M., OReilly, A., \& Matathia, I. (2004). Buzz ... le marketing du bouche à oreille. Paris: Village Mondial.

Scoble, R., \& Israel, S. (2006). Naked conversations: How blogs are changing the way businesses talk with customers. Hoboken, New Jersey: John Wiley \& Sons.

Severi, E., Ling, K. C., \& Nasermoadeli, A. (2014). The impacts of electronic word of mouth on brand equity in the context of social media. International Journal of Business and Management, 9(8), 84. https://doi.org/10.5539/ijbm.v9n8p84

Stephen, A. T., \& Toubia, O. (2010). Deriving value from social commerce networks. Journal of Marketing Research, 47(2), 215-228.

https://doi.org/10.1509/jmkr.47.2.215

Top, S., Dilek, S., \& Çolakoğlu, N. (2011). Perceptions of network effects: Positive or 
negative externalities? Procedia-Social and Behavioral Sciences, 24, 1574-1584.

Tsai, H. T., \& Pai, P. (2013). Explaining members' proactive participation in virtual communities. International Journal of Human-Computer Studies, 71(4), 475-491. https://doi.org/10.1016/j.sbspro.2011.09.033

Riel, A. C. V., Liljander, V., \& Jurriëns, P. (2001). Exploring consumer evaluations of e-services: a portal site. International Journal of Service Industry Management, 12(4), 359-377. doi: 10.1108/09564230110405280

Yang, Z., \& Jun, M. (2002). Consumer perception of e-service quality: From internet purchaser and non-purchaser perspectives. Journal of Business strategies, 19(1), 19-41.

Yang, Z., \& Peterson, R. T. (2004). Customer perceived value, satisfaction, and loyalty: The role of switching costs. Psychology \& Marketing, 21(10), 799-822. https://doi.org/10.1002/mar.20030

Zehir, C., Sehitoglu, Y., Narcikara, E., \& Zehir, S. (2014). ES-quality, perceived value and loyalty intentions relationships in internet retailers. Procedia-Social and Behavioral Sciences, 150, 1071-1079. https://doi.org/10.1016/j.sbspro.2014.09.120

Zeithaml, V. A., Parasuraman, A., \& Malhotra, A. (2002). Service quality delivery through web sites: A critical review of extant knowledge. Journal of the academy of marketing science, 30(4), 362-375. https://doi.org/10.1177/009207002236911

Zhao, L., Lu, Y., Wang, B., Chau, P. Y. K., \& Zhang, L. (2012). Cultivating the sense of belonging and motivating user participation in virtual communities: A social capital perspective. International Journal of Information Management, 32(6), 574588. https://doi.org/10.1016/j.ijinfomgt.2012.02.006

Zhou, S., Feng, D., Xu, Y., \& Zhou, Y. (2012). Influencing factors of credibility in C2C ecommerce web sites. Procedia Engineering, 29, 509-513.

https://doi.org/10.1016/j.proeng.2011.12.752

PIXLEE (2015). Making the Case for Social Commerce. PIXLEE. Retrieved from http://blog.pixlee.com/the-case-for-social-commerce

Dr. I-Ping Chiang (Corresponding author) is currently a professor of Graduate Institute of Information Management, National Taipei University. His current research interests include social marketing, online behavior, and internet marketing. He published more than one hundred articles.

Mr. Kai-Chieh Lin graduated from Graduate Institute of Information Management, National Taipei University.

Ms. Chih-Hui Huang graduated from Graduate Institute of Information Management, National Taipei University. 
Ms. Wan-Ling Yang is currently studying in Graduate Institute of Information Management, National Taipei University. 